\title{
RESULTS OF THE BIOLOGICAL TEST OF SIMMENTAL BULLS IN CENTRAL SERBIA
}

\author{
D. Nikšić ${ }^{1}$, V. Pantelić ${ }^{1}$, D. Ostojić-Andrić ${ }^{1}$, P. Perišić ${ }^{2}$, M. Petričević ${ }^{1}$, R. \\ Đedović $^{2}$, M. Lazarević ${ }^{1}$ \\ ${ }^{1}$ Institute for Animal Husbandry, Autoput 16, P. Box 23, 11080, Belgrade-Zemun, Republic of Serbia \\ ${ }^{2}$ Faculty of Agriculture University of Belgrade, Nemanjina 6, 11080 Belgrade, Republic of Serbia \\ Corresponding author: draganniksic84@gmail.com \\ Original scientific paper
}

Abstract: Exceptionally important aspect in cattle production, from the aspect of production and economy, is ensuring normal and regular fertility. Every cattle breeder wants to have high-yielding animals which at the same time have good fertility. In proper cattle breeding this means that from each cow during single year one healthy calf is obtained. Use of artificial insemination has enabled that one breeding male is used as sire for several tens of thousands of progeny, however, there is always the risk that sires could be carriers of lethal and semi-lethal genes, which can cause huge losses of calves. In order to bring these undesirable occurences to a minimum, so called bilogical test is included in the breeding and selection activities, i.e. bulls are tested through their progeny for presence of difficult calving (dystocia) abd calf losses caused by genetic anomalies. In Republic of Serbia, this test is carried out on ehtire Simmental population in an exchange of data produced by primary breeding organizations. Per each tested bull, it is necessary to have data on minimum 50 randomly selected calves. Calves are examined visually 65 days after the birth, at the latest. In the present study, the results of the biological testing of 35 Simmental bulls, sires of total 3572 calves on the territory of Central Serbia, in the period 2008-2009, are used. The effect of sires on parameters of biological test were studied: body mass of calves at birth, calf score and calving score. Also, bulls were ranked based on said parameters, male/female calves ratio and percentage of twins and still-born calves for each bull individually were determined. After the rank of bulls was established, the correlation between the rank and studied fertility traits was determined. Correlations were expressed using the Spearman coefficient. Research results show that the effect of bulls was very high $\mathrm{p}<0,001$ on all three parameters of the biological test, and also that the percentage of still born calves for all bulls was within limits, with the exception of bulls Zahlo (HB 1497) and Woz (HB 1433) where it was above 5 .

Key words: biological test, bulls, Simmental breed 


\section{Introduction}

For present trends in modern production of milk and meat it is absolutely unacceptable to have one-sided selection for productive traits only, because it can greatly contribute to numerous metabolic disorders and shortening of productive life. Modern/contemporary breeding goals and programs are focused primarily on reaching and maintaining of the optimal balance between productive and functional traits without any health risk and compromising of animals' ethological characteristics (Ostojić-Andrić et al., 2011). Regardless of the breeding goal and defined program, fertility and fitness traits must be iontegrated, i.e. traits of resistance to diseases (Trivunović et al., 2011).

Biological test provides the right information on breeding value of bulls in the progeny testing. It includes study of bulls in terms of inheritance of degenerative properties, potential incidence of calves with congenital deficiencies and defects, lethal and semi-lethal factors which ensures acurate insight of the quality of calves obtained from individual bull sire. With this test, practically, it is established if breeding male is carrier of lethal, semi-lethal or harmful genes, where:

- Lethal genes cause death of the progeny during gestation/gravidity, during or immediately post- parturition;

- Semi-lethal genes cause birth of avital progeny which dies shortly after birth, or some time subsequent to parturition;

- Harmful genes which do not cause directly the death of calves, but induce diminishing of the vitality and resistance of progeny of harmful genes.

Biological test starts at the moment when young bulls collect the first 750 doses of semen. In that period, according to pre-defined schedule, semen is distributed to farms and cows and heifers are inseminated randomly Đedović (2004).

Biological test of young bulls is carried out in production conditions of the population. In order to establish if potential breeding male is carrier of undesirable genes (lethal, semi-lethal or harmful genes), it is necessary to study at least 50 calves. Calves are examined in the first month subsequent to parturition (at latest 65 days post partum), and focus is usually on 10 defects, and which of them will be included in the test depends on the specific population.

Fertility is almost regularly the first limiting factor in milk production. One of the most important reproductive traits is body mass of calves at birth. It is considered as one of the major traits which influence the calving progress, when there is objective risk of incidence of difficult calving (dystocia) and calf mortality Johanson and Berger, (2003); Linden et al., (2009). In case of difficult calving (dystocia), the main issue is disproportion of the fetus size and birth canals of the dam, which is most often case with first calving females, as stated by Martinez et 
al.,(1983) and Lombard et al. (2007). The expression of this trait is also influenced by hereditary and environment factors, the most important are the following: breed, calf sex/gender, calving order, duration of gravidity, dam's age, duration of dry period, dam's body mass, breeding/rearing and nutrition as stated by Latinović et al.,(1983); Skalicki et al., (1991); Trifunović et al. (1998).

In the present study production results of Simmental bulls are analyzed and cow fertility results in period 2008 - 2009 presented, in order to present to scientific community the genetic potential of Serbia's cattle population in terms of productivity of bulls and fertility of cows of Simmental breed and also to indicate the frequency of incidence of still born calves and calves with anomalies.

\section{Materials and Methods}

The data recorded by the Main Breeding Organization - Institute for Animal husbandry, Belgrade-Zemun, was used in the present study. Biological test was done on 35 bulls of Simmental breed with data on 3.572 calves, born in the period from 2008 to 2009 on the territory of Central Serbia. Analysis included following traits: body mass at birth (BMB), calf score at birth (CSB), calving score (CS), type of birth (TB), number of still born calves (SBC) and sex ratio.

Frequencey, i.e. percentage values were determined for calf score at birth, calving score, type of birth and number of still born calves. The effect of sires on variability of traits (body mass of calves, calf score at birth, calving score) observed in the biological test was determined using single factor variance analysis $(p<0.001)$. In addition to determination of the sire effect, bulls were ranked according to mean values obtained for all three parameters in the biological test, as well as number of still born calves, sex ratio and number of twin births for each individual bull. Subsequent to ranking of bulls, the correlation between the bull rank ans studied fertility traits was analyzed. Correlations were expressed using the Spearman coefficient.

Obtained data were analyzed using statistical program StatSoft.Inc (2004), Statistica for Windows version 7, where minimum, mean and maximum values were determined, as well as variability indicators (standard deviation - SD, coefficient of variation - CV and standard error- Se).

\section{Results and discussion}

In Table 1 the results of the descriptive statistics for 3 traits in the biological test are presented. If the fact is considered that calves in combined production have higher body mass at birth than calves in dairy production, obtained results in this study are very similar to results obtained by Đedović (2004) for Holstein-Friesian breed, and slightly higher compared to results obtained by 
Novaković et al. (2012) in the study of the effect of numerous systematic factors on fertility parameters of the biological test. In the same study, the presence of significant variability in regard to body mass at birth between sires was established.

Table 1. Mean values and variability of traits in the biological test

\begin{tabular}{|l|c|c|c|c|c|c|}
\hline Traits & $\mathbf{x}$ & $\mathbf{m i n}$ & $\mathbf{m a x}$ & SD & CV & Se \\
\hline Body mass at birth & 44,54 & 25 & 73 & 5,27 & 11,03 & 0,09 \\
\hline Calf score at birth & 4,53 & 2 & 5 & 0,59 & 13,02 & 0,01 \\
\hline Calving score & 4,66 & 2 & 5 & 0,55 & 11,8 & 0,01 \\
\hline
\end{tabular}

In the analysis of variance it was established that all three traits in the biological test vary significantly $(p<0.001)$ under the influence of bull-sires (Table 2). It can be concluded that right chocie of bulls (sires) leads to avoiding of incidence of calves with anomalies. Anomalies which occured were mainly caused by genes which weren't lethal. These anomalies are at the same time the most frequent anomalies in calves of simmental breed in our country: no tail, blidness, rabbit lip, albinism and chimerism.

\begin{tabular}{|l|c|}
\hline \multicolumn{2}{|l|}{ Table 2. The effect of sires on fertility traits } \\
\hline \multirow{2}{*}{ Trait } & $\begin{array}{c}\text { Source of } \\
\text { variability }\end{array}$ \\
\cline { 2 - 2 } & Bull-sire \\
\hline Body mass at birth & $55,64^{* * *}$ \\
\hline Calf score at birth & $98,16^{* * *}$ \\
\hline Calving score & $61,03^{* * *}$ \\
\hline
\end{tabular}

The application of artificial insemination and progress in the technology of cattle breeding and rearing have enabled obtaining and selection of bull with multiple good traits to be used in breeding and fertilization. In the selection of bull sires and dam sires the greatest genetical progress is realized, even $85 \%$, in population of Simmental cattle. In Serbia, the insemination is mainly done with the semen of foreign bulls and to lesser extent with semen from of domestic bulls, Nikšić et al. (2011). Progeny tested bull must have all breeding traits determined in the breeding program. Based on these criteria, bulls are selected to be used in breeding with those traits that are deficient in certain population or herd, and are expressed in specific bull or transmitted to progeny. In next table (Table 3) all bulls used in the biological test in 2008 and 2009 are ranked based on average 
Table 3. Rank of bulls for studied fertility traits based on average values

\begin{tabular}{|c|c|c|c|c|c|c|c|}
\hline $\begin{array}{c}\text { Bull } \\
\text { name }\end{array}$ & $\begin{array}{l}\text { Bull } \\
\text { HB }\end{array}$ & $\begin{array}{l}\text { Body mass } \\
\text { at birth }\end{array}$ & Rank & $\begin{array}{c}\text { Calf } \\
\text { score at } \\
\text { birth }\end{array}$ & Rank & $\begin{array}{c}\text { Calving } \\
\text { score }\end{array}$ & Rank \\
\hline DIETER & 1427 & 44,74 & 14 & 4,68 & 18 & 4,77 & 20 \\
\hline STIER & 1492 & 43,99 & 19 & 4,28 & 24 & 4,78 & 19 \\
\hline DONER & B158 & 42,33 & 30 & 4,25 & 25 & 4,62 & 26 \\
\hline HUMSTREIF & B206 & 43,02 & 24 & 3,95 & 32 & 5 & 1 \\
\hline WEHOR & B213 & 42,93 & 26 & 3,91 & 33 & 5 & 2 \\
\hline ERFAS & 1352 & 54,2 & 1 & 5 & 1 & 5 & 3 \\
\hline FAO & B19 & 42,99 & 25 & 4,13 & 27 & 4,09 & 32 \\
\hline FEST & B145 & 43,8 & 21 & 4,14 & 26 & 4,05 & 33 \\
\hline HOFAL & 1500 & 43,28 & 23 & 4,12 & 30 & 4,03 & 34 \\
\hline ZASTRADA & 1453 & 49,25 & 4 & 4,8 & 16 & 4,75 & 22 \\
\hline WEIPORT & V026 & 50,79 & 2 & 4,93 & 10 & 4,55 & 28 \\
\hline HORMAZ & 1488 & 48,36 & 7 & 4,56 & 21 & 4,79 & 17 \\
\hline HORMIT & 1470 & 49,6 & 3 & 4,52 & 22 & 4,57 & 27 \\
\hline VALBO & B279 & 44,38 & 15 & 4,64 & 19 & 4,86 & 12 \\
\hline ZAHLO & 1497 & 45,54 & 10 & 4,63 & 20 & 4,66 & 25 \\
\hline RAUBECK & 1507 & 44,2 & 18 & 3,81 & 34 & 4,99 & 4 \\
\hline WOZ & 1433 & 42,09 & 31 & 3,6 & 35 & 4,87 & 10 \\
\hline HODAR & B68 & 43,35 & 22 & 4,07 & 31 & 3,99 & 35 \\
\hline RADEX & B51 & 43,97 & 20 & 4,13 & 28 & 4,12 & 30 \\
\hline RAŠA & V626 & 48,95 & 5 & 4,76 & 17 & 4,87 & 11 \\
\hline VALIAN & 1501 & 48,89 & 6 & 4,97 & 4 & 4,97 & 5 \\
\hline PORTO & B118 & 42,51 & 28 & 4,87 & 13 & 4,92 & 7 \\
\hline FEBRO & B50 & 46,17 & 9 & 4,83 & 15 & 4,77 & 21 \\
\hline HODBAL & B275 & 44,96 & 12 & 4,94 & 9 & 4,79 & 18 \\
\hline DION & B244 & 44,32 & 17 & 4,96 & 6 & 4,81 & 15 \\
\hline MOOR & 1504 & 44,83 & 13 & 4,95 & 7 & 4,84 & 13 \\
\hline MARNOLD & 1508 & 44,35 & 16 & 4,95 & 8 & 4,84 & 14 \\
\hline HORAU & 1411 & 40,43 & 33 & 5 & 2 & 4,67 & 24 \\
\hline MOBI & B112 & 40,35 & 34 & 4,9 & 12 & 4,74 & 23 \\
\hline LEO & B164 & 39,61 & 35 & 4,34 & 23 & 4,27 & 29 \\
\hline REPRON & 1479 & 45,28 & 11 & 4,92 & 11 & 4,92 & 8 \\
\hline MARMAL & B333 & 42,68 & 27 & 4,98 & 3 & 4,9 & 9 \\
\hline MALINT & B232 & 47,78 & 8 & 4,13 & 29 & 4,12 & 31 \\
\hline MILAN & V1023 & 41,21 & 32 & 4,84 & 14 & 4,8 & 16 \\
\hline VEBER & B307 & 42,47 & 29 & 4,97 & 5 & 4,97 & 6 \\
\hline
\end{tabular}


values of body mass of calves, calf scores and calving scores. The best ranked bulls are Erfas HB 1352 for body mass at birth and calf score at birth, and for calving score the best ranked bull is Humstreif HB B206.

Subsequent to ranking of bulls, the level of concurrence between obtained ranks was tested. Table 4 presents correlation coefficients expressed by Spearman coefficient. Between bull ranks weak and positive correlation was determined in the range from 0,042 to 0,285 , which enables carrying out of direct selection. It is particularly important that the correlation is positive, it means that highly ranked bull in regard to calving score can produce calves with acceptable body mass at birth.

\begin{tabular}{|c|c|c|}
\hline \multicolumn{2}{|c|}{ Table 4. Correlations of bull ranks } \\
\hline \multicolumn{2}{|c|}{ Rank } & Rank correlation \\
\hline BMB & CSB & $0,202 * *$ \\
\hline BMB & CS & $0,042 * *$ \\
\hline CSB & CS & $0,285^{* *}$ \\
\hline
\end{tabular}

In this study, many parameters of the biological test were studied for each bull individually (Table 5). By comparing these results it can be established that the total percentage of still born calves was significantly lower $(1,23 \%)$ compared to results obtained by Gottschalk et al. (1983). Considering that bulls Zahlo HB 1497 and Woz HB 1433 had more than $5 \%$ of still born calves they were negative in the biological test, and as such excluded from breeding.

One of the most important factors influencing the change in the gene frequency of population is the bull semen used in artificial insemination. Therefore it is very important to establish for each bull the presence of genes which influence the equal sex ratio of the progeny. In conditions of artificial insemination, bulls which produce approximately $50 \%$ of male and $50 \%$ of female offspring are prefered. According to data used in the present study (Table 5), it was calculated that in average more female calves $(54,16 \%)$ are born than males $(45,84 \%)$.

In the present study also the type of birth was determined (Table 5). Type of birth means number of calves born per one parturition, i.e. if the result of calving was single calf, twins or triplets. Of total number of calves 3752 , there were no triplets, and number of twins was 170 which is approximately $4,76 \%$,

Also, the percentage values i.e. presence of calving scores for each bull individually were calculated. Number of calves born by Cesarean cut was exceptionally low -5 . Dams which underwent the Cesarean cut were inseminated with semen of bulls Mobi HB B112 (2), Febro B50, Marmal B333 and Milan V1023 (Table 5).

Since it is known that difficult calving (dystocia) has equaly adverse effect on production of milk and meat, and knowing that body mass of calves at birth is 
highly hereditary, bull sires with genes for high body mass of calves should not be used for insemination of heifers and cows of easier type.

Table 5. Fertility parameters for each individual bull

\begin{tabular}{|c|c|c|c|c|c|c|c|c|c|c|}
\hline & \multirow{2}{*}{ Bull name } & \multirow{2}{*}{$\begin{array}{l}\text { Bull } \\
\text { HB }\end{array}$} & \multirow{2}{*}{$\begin{array}{c}\text { Number } \\
\text { of } \\
\text { calves }\end{array}$} & \multicolumn{4}{|c|}{ Calving score } & \multicolumn{3}{|c|}{ Comments } \\
\hline & & & & 5 & 4 & 3 & 2 & MR & $\mathrm{BL}$ & $\begin{array}{c}\text { Sex ratio } \\
(\mathrm{m}-\mathrm{f})\end{array}$ \\
\hline 1 & DIETER & 1427 & 101 & 87 & 5 & 9 & - & 4 & 10 & $39-62$ \\
\hline 2 & STIER & 1492 & 96 & 80 & 11 & 5 & - & 2 & 4 & $32-64$ \\
\hline 3 & DONER & B158 & 97 & 74 & 9 & 14 & - & 4 & 12 & $50-47$ \\
\hline 4 & HUMSTREIF & $206 \mathrm{~B}$ & 116 & 116 & - & - & - & - & - & $47-69$ \\
\hline 5 & WEHOR & 213B & 109 & 108 & - & - & - & - & - & $57-52$ \\
\hline 6 & ERFAS & 1352 & 95 & 95 & - & - & - & - & 10 & $49-46$ \\
\hline 7 & FAO & B19 & 92 & 8 & 84 & - & - & - & 6 & $39-53$ \\
\hline 8 & FEST & B145 & 85 & 4 & 81 & - & - & - & 3 & $34-51$ \\
\hline 9 & HOFAL & 1500 & 249 & 10 & 236 & 3 & - & 1 & 7 & $115-134$ \\
\hline 10 & ZASTRADA & 1453 & 81 & 61 & 20 & - & - & - & 6 & $43-38$ \\
\hline 11 & WEIPORT & V026 & 94 & 52 & 42 & - & - & - & 10 & $25-69$ \\
\hline 12 & HORMAZ & 1488 & 81 & 69 & 7 & 5 & - & - & - & $34-47$ \\
\hline 13 & HORMIT & 1470 & 92 & 65 & 14 & 13 & - & - & - & $48-44$ \\
\hline 14 & VALBO B & 279 & 100 & 86 & 14 & - & - & 2 & 10 & $46-54$ \\
\hline 15 & ZAHLO & 1497 & 95 & 75 & 8 & 12 & - & 9 & 8 & $47-48$ \\
\hline 16 & RAUBECK & 1507 & 85 & 84 & 1 & - & - & - & 2 & $43-42$ \\
\hline 17 & WOZ & 1433 & 92 & 85 & 2 & 5 & - & 5 & - & $45-47$ \\
\hline 18 & HODAR & B68 & 89 & 1 & 86 & 2 & - & 1 & 6 & $42-47$ \\
\hline 19 & RADEX & B51 & 89 & 11 & 78 & - & - & - & 8 & $48-41$ \\
\hline 20 & RAŠA & V626 & 87 & 76 & 11 & - & - & - & - & $34-53$ \\
\hline 21 & VALIAN & 1501 & 91 & 89 & 1 & 1 & - & 2 & 12 & $31-60$ \\
\hline 22 & PORTO & B118 & 111 & 103 & 7 & 1 & - & 5 & 14 & $34-77$ \\
\hline 23 & FEBRO & 50 & 81 & 65 & 14 & 1 & 1 & 1 & - & $46-35$ \\
\hline 24 & HODBAL & B275 & 89 & 70 & 19 & - & - & 1 & 4 & $49-40$ \\
\hline 25 & DION & B244 & 100 & 81 & 19 & - & - & - & 4 & $53-47$ \\
\hline 26 & MOOR & 1504 & 81 & 68 & 13 & - & - & - & 2 & $40-41$ \\
\hline 27 & MARNOLD & 1508 & 80 & 67 & 13 & - & - & - & 4 & $44-36$ \\
\hline 28 & HORAU & 1411 & 96 & 72 & 16 & 8 & - & - & 2 & $39-57$ \\
\hline 29 & MOBI & B112 & 117 & 95 & 15 & 5 & 2 & 2 & 2 & $60-57$ \\
\hline 30 & LEO & B164 & 128 & 53 & 57 & 18 & - & - & 2 & $69-59$ \\
\hline 31 & REPRON & 1479 & 172 & 159 & 13 & - & - & 2 & - & 71-101 \\
\hline 32 & MARMAL & B333 & 126 & 116 & 9 & - & 1 & 2 & 2 & $57-69$ \\
\hline 33 & MALINT & B232 & 93 & 26 & 52 & 15 & - & - & 2 & $45-48$ \\
\hline 34 & MILAN & V1023 & 92 & 76 & 15 & - & 1 & 1 & 14 & $43-49$ \\
\hline 35 & VEBER & B307 & 91 & 88 & 3 & - & - & - & 4 & $40-51$ \\
\hline
\end{tabular}

In Table 6, the number and percentage of calves for each individual trait are presented. By observing the results related to calf score and low incidence of 
anomalies, most of calves were scored 5 and 4, or around 96\%. Obtained results are consistent witjh results obtained by Đedovic 2004., whereas results related to calving score were consistent with results obtained by H. Karb et al. (1988).

\begin{tabular}{|c|c|c|c|c|c|}
\hline \multicolumn{6}{|c|}{ Table 6. Number and percentage of calves according to individual scores } \\
\hline $\begin{array}{c}\text { Calf } \\
\text { scores }\end{array}$ & $\begin{array}{c}\text { Number } \\
\text { of calves }\end{array}$ & $\begin{array}{c}\text { Percentage } \\
\text { of calves }\end{array}$ & Calving score & $\begin{array}{c}\text { Number } \\
\text { of calves }\end{array}$ & $\begin{array}{c}\text { Percentage } \\
\text { of calves }\end{array}$ \\
\hline 5 & 2069 & 57,93 & 5 & 2475 & 69,29 \\
\hline 4 & 1364 & 38,18 & 4 & 975 & 27 \\
\hline 3 & 121 & 3,39 & 3 & 117 & 3,28 \\
\hline 2 & 18 & 0,5 & 2 & 5 & 0,14 \\
\hline
\end{tabular}

\section{Conclusion}

In this study, the effect of bull sires on certain fertility parameters in biological test was determined. Also, results for each bull individually were determined.

Based on conducted research and obtained results it can be concluded that the number of bulls who gave still born or calves with anomalies was very low, whereas the number of calves receiving the highest scores was exceptionally high. Sex ratio was close to the ideal 50\%:50\%, and percentage of twin births was close to 5 .

The right choice of bulls as future breeding animals can be way to improve fertility traits and calving type. The use of tested bulls which are simultaneously tested for milk traits, milking traits and body development traits as well as presence of congenital anomalies and defects will influence the reduction of frequency of undesirable genes in populations of Simmental cattle.

In this study, 35 bulls were ranked based on the average values of traits in the biological test.

Bull ranking is important for selection experts and breeders because the right selection of bull enables faster and more efficient realization of the breeding goal. The choice depends on the primary operation of the breeder, who by viewing the ranking of bulls can easily select adequate bull. The right choice of bull is also imposed by the fact that in conditions of artificial insemination bull have considerably higher intensity of fertility than cows.

Anaysis of obtained results and adequate distribution of semen of tested and positvely scored and evaluated bulls in the biological test can contribute to expression of positive results in improvement of fertility traits. Considering that bulls have statistically influenced traits observed in the biological test, with rught selection of future breeding sires it is possible to improve fertility traits and suppress undesirable genes. 
In view of all stated in the present study, the research of the evaluation of the breeding value of cattle should be continued and also all known data associated with the inherent variability of fertilit traits should be included, since in this way the long term increase of the effects of applied selection in studied cattle selection will be realized.

\section{Acknowledgment}

Research was financed by the Ministry of Education, Science and Technological Development of the Republic of Serbia, project TR31053.

\section{Rezultati biološkog testa bikova simentalske rase u Centralnoj Srbiji}

D. Nikšić, V. Pantelić, D. Ostojić-Andrić, P. Perišić, M. Petričević, R. Đedović, M. Lazarević

\section{Rezime}

Izuzetno važan aspekt u govedarskoj proizvodnji, gledano sa proizvodnog $\mathrm{i}$ ekonomskog stanovišta je obezbeđivanje normalne i redovne plodnosti. Svaki odgajivač goveda želi da ima grla koja su visoko proizvodna i istovremeno poseduju dobru plodnost. Za pravilno odgajivanje goveda to znači da se od svake krave $\mathrm{u}$ toku godine dobije po jedno zdravo tele. Upotreba veštačkog osemenjavanja omogućila je da jedan priplodnjak bude otac nekoliko desetina hiljada potomaka. Međutim, uvek postoji rizik da su očevi nosioci letalnih i semiletalnih gena, što može prouzrokovati velike gubitke teladi. Da bi se ove nepoželjne pojave svele na najmanju moguću meru u odgajivački i selekcijski rad uključeno je ispitivanje bikova po potomstvu na teška teljenja i gubitke teladi izazvane genetskim anomalijama, tzv. biološki test. Ovaj test se u Republici Srbiji vrši jedinstveno za čitavu populaciju simentalske rase, razmenom podataka između odgajivačkih organizacija. Po svakom biku koji se testira, neophodno je imati podatke za najmanje 50 slučajno odabrane teladi. Vizualni pregled teladi se obavlja najkasnije do 65 dana, od datuma rođenja teleta. U ovom istraživanju korišćeni su rezultati biološkog testa 35 bikova simentalske rase koji su bili očevi ukupno 3572 teladi na teritoriji centralne Srbije u periodu 2008. i 2009. godine. U radu je ispitivan uticaj očeva na parametre biološkog testa: telesnu masu teladi po rođenju, ocenu teleta i ocenu toka teljenja. Takođe je izvršeno rangiranje bikova na ove parametre, kao i utvrđivanje odnosa muške i ženske teladi, procenat bližnjenja kao 
i procenat mrtvorođene teladi za svakog bika posebno. Nakon utvrđenog ranga bikova izvršena je korelacija ranga ispitivanih osobina plodnosti. Korelacije su iskazane Spirmanovim koeficijentom. Rezultati istraživanja pokazali su da je uticaj bikova izuzetno visok $\mathrm{p}<0,001$ na sva tri parametra u biološkom testu, kao i da je procenat mrtvorođene teladi kod svih bikova u dozvoljenim granica, osim bikova Zahlo (HB 1497) i Woz (HB 1433) gde je iznosio preko 5.

\section{References}

ĐEDOVIĆ R. (2004): Genetska varijabilnost i povezanost osobina plodnosti praćenih u progenom testu bikova holštajn frizijske rase, Doktorska disertacija GOTTSCHALK A: (1983): Rinderzuch und Rinderhaltung, Frankfurt/M.

JOHANSON J. M., P. J. BERGER. (2003): Birth Weight as a Predictor of Calving Ease and Perinatal Mortality in Holstein Cattle. J. Dairy Sci. 86: 3745-3755.

KARB H., KARRAS K. (1988): Zuchtwertschätzung auf Leichtkalbigkeit. Der Tierzüchter, 3, 102-103,.

LATINOVIĆ D., LAZAREVIĆ LJ., PAVLOV B., PANIĆ M. (1983): Efekat unošenja gena holštajna na neka reproduktivna svojstva u populacijama crno-belih krava PK"Beograd". Stručni odbor za govedarstvo i proizvodnju stočne hrane, 18, 39-45. Beograd.

LINDEN T. C., BICALHO R.C., NYDAM D.V. (2009): Calf birth weight and its association with calf and cow survivability, disease incidence, reproductive performance, and milk production. J. Dairy Sci. 92:2580-2588.

LOMBARD J. E., GARRY F.B., TOMLINSON S.M., GARBER L.P.. (2007): Impacts of Dystocia on Health and Survival of Dairy Calves. J. Dairy Sci. 90:1751-1760.

MARTINEZ MARIO L., FREEMAN A.E., BERGER P.J.. (1983): Factors Affecting Calf Livability for Holsteins. J. Dairy Sci 66: 2400-2407.

NIKŠIĆ D., OSTOJIĆ-ANDRIĆ D., PANTELIĆ V., PERIŠIĆ P., NOVAKOVIĆ Ž., ALEKSIĆ S., LAZAREVIĆ M. (2011): Production potential of first calving Simmental heifers in Serbia. $3^{\text {rd }}$ International Congress "New Perspectives and Challenges of Sustainable Livestock Production", Belgrade, October $5^{\text {th }}$ to $7^{\text {th }}$, 2011, Biotechnology in Animal Husbandry, Vol. 27 (3), p. 1033-1043.

NOVAKOVIĆ Ž., SRETENOVIĆ LJ., PETROVIĆ M.M., ALEKSIĆ S., PANTELIĆ V., OSTOJIĆ-ANDRIĆ D., NIKŠIĆ D. (2012): The effect of certain systematic factors on body mass of calves of high yielding cows at birth. Journal of mountain agriculture on the balkans, Vol. 15 (4), p. 759-769.

OSTOJIĆ-ANDRIĆ D., HRISTOV S., NOVAKOVIĆ Ž., PANTELIĆ V., PETROVIĆ M. M., ZLATANOVIĆ Z., NIKŠIĆ D. (2011): Dairy Cows Welfare Quality In Loose Vs. Tie Housing System. $3^{\text {rd }}$ International Congress "New 
perspectives and Challenges of Sustainable Livestock production"Belgrade, Republic of Serbia, 5-7 ${ }^{\text {th }}$ October 2011. Biotechnology in Animal Husbandry vol 27, 3, Book 2, p.975-984

SKALICKI Z., LATINOVIĆ D., LAZAREVIĆ LJ., STOJIĆ P. (1991): Fenotipske karakteristike reproduktivnih osobina crno-belih goveda sa različitom proporcijom gena holštajn-frizijske rase. Zbornik radova poljoprivrednog fakulteta, radovi sa VII naučnog skupa zootehničara Jugoslavije, 2, 33, Beograd.

STATISTICA FOR WINDOWS VERSION 7. StatSoft.Inc (2004), Oxford, UK TRIFUNOVIĆ G., LAZAREVIĆ LJ., LATINOVIĆ D., STOJIĆ P., STEVANOVIĆ LJ. (1998): Analiza mlečnosti i plodnosti krava tokom prve tri laktacije gajenih slobodnim sistemom držanja. Savremena poljoprivreda br. 1-2, str.49-54. Novi Sad.

TRIVUNOVIĆ S., IVANOVIĆ D., KUČEVIĆ D., PANTELIĆ V., KORORA J., RADINOVIĆ M. (2011): Genetski parametri za pojavu teških teljenja i broj mrtvorođene teladi u populaciji krava holštajn frizijske rase vojvodine, Biotechnology in Animal Husbandry, Vol 27 , Beograd 